\title{
Agronomic performance of Safflower genotypes (Carthamus tinctorius L.) under different soil bulk density levels in the Oxisol of the Cerrado
}

\author{
Juliana Terezinha Sasso Paludo ${ }^{1}$, Edna Maria Bonfim-Silva ${ }^{1}$, Tonny José Araújo da Silva ${ }^{1}$, Helon Hébano de \\ Freitas Sousa ${ }^{1}$, Maurício Dutra Zanotto ${ }^{2}$, William Fenner ${ }^{1}$ \\ ${ }^{1}$ Federal University of Mato Grosso - UFMT, Institute of Agricultural and Technological Sciences, 5055 Students \\ Avenue Rondonópolis, 78.735-901, Brazil \\ ${ }^{2}$ São Paulo State University - UNESP, Department of Production and Plant Breeding, 215 Street Quirino de Andrade, \\ 01.049-010, Brazil
}

\section{Abstract}

As intensive farm development can cause changes in soil structure, it is crucial to study cultivars that can adapt to these changes, along with the climatic conditions of the Cerrado of Mato Grosso. The objective of this study is to assess the effects of soil bulk density (weight of soil in a given volume) on the agronomic performance of the safflower genotypes (Carthamus tinctorius L.). The experiment was conducted at the Federal University of Mato Grosso in a greenhouse. A completely randomized design in factorial scheme with four replications was selected. The treatments comprised of five soil bulk density levels $(1.0,1.2,1.4,1.6$ and $1.8 \mathrm{Mg}$ $\mathrm{m}^{-3}$ ) and ten safflower genotypes (PI 237538, PI 248385, PI 250196, PI 301049, PI 305173, PI 305205, PI 306596, PI 306603, PI 560202 and PI 613366). The following evaluations were done after completion of the experiments: total shoot dry mass, upper ring root dry mass, intermediate and lower total root dry mass. The data were subjected to the analysis of variance and the means were categorized by the Scott-Knott test at the $5 \%$ level of probability. The genotypes and soil bulk density influenced the components in isolation ways. The shoot dry mass production was impaired from the bulk density of $1.10 \mathrm{Mg} \mathrm{m}^{-3}$. For the root dry mass, the limit was $1.04 \mathrm{Mg} \mathrm{m}^{-3}$. In general, from the soil density of $1.20 \mathrm{Mg} \mathrm{m}^{-3}$ the growth and development of safflower genotypes were influenced negatively. The increase in soil density reduced the total root dry mass up to $71.11 \%$.

Keywords: Carthamus tinctorius L., oleaginous plants, root development, soil compaction, plant physiology.

Abbreviations: CAPES_Coordenação de Aperfeiçoamento de Pessoal de Nível Superior; CNPq_Conselho Nacional de Desenvolvimento Científico e Tecnológico; DAE_Days After Emergency; RDMC_Root Dry Mass in the Compacted Ring; RDML_Root Dry Mass in the Lower Ring; RDMU_ Root Dry Mass of Upper Ring; FTE_ Fritted Trace Elements; IMA_ Mato Grosso Cotton Institute; PVC_ Polyvinyl chloride; TRDM_ Total Root Dry Mass; TSDM_ Total Shoot Dry Mass; UNESP_Universidade Estadual Paulista "Júlio de Mesquita Filho".

\section{Introduction}

As the crop yield is significantly and directly affected by the physical characteristics of the soil, a thorough understanding and comprehensive study of the soil will enable higher yield production. Considering this aspect, soil compaction, among the other factors, may decrease the nutrient absorption by the plants; thus, hindering their development (Leite et al., 2013).

Alterations in root growth, absorption of water and nutrients, concentrations on root at superficial layers are common problems in agricultural systems in the world (Marschner, 1986). Studies reported the concentration of roots in the $0.0-0.15 \mathrm{~m}$ layer, when bulk density is $1.72 \mathrm{Mg}$ $\mathrm{m}^{-3}$ (Rosolem et al., 1994).

Although similar conditions are anticipated in different regions of the same biome, agricultural exploitation precipitates unfavorable situations under the natural conditions, such as causing physical alterations in the soils. Safflower has been cultivated for more than four thousand years, as proven by seeds found in Egypt. It is now raised in every continent worldwide (Coronado, 2010).

Since the responses to the environment vary between cultivars and species; thus, it is essential to know the responses of crop to soil compaction and discussion of management strategies that allow the viability of the agricultural system as well as the incorporation of new crops to the productive system (Marasca et al., 2011; Valicheski et al., 2012). Therefore, it becomes crucial to study new cultures to enable them to adapt the changing soil conditions, as well the climate of the Cerrado of Mato Grosso.

One alternative is that safflower (Carthamus tinctorius L.) can be introduced in to the Brazilian Cerrado, during the interval between harvests to facilitate diversification in the farms (Bonfim-Silva et al., 2015). According to recent researches, reproductive compounds of safflower genotypes are negatively affected at Oxisol bulk density mean of 1.2 
$\mathrm{Mg} \mathrm{m}^{-3}$ (Paludo et al., 2017). The safflower seeds possess high oil content (35-45\%), good in quality and suitable as edible and industrial oil. The high oleic acid content (70-75\%) and linoleic acid (70-75\%) of safflower oil enables the classification of these commercial cultivars into the oleic and linoleic groups based on the percentage of these fatty acids (Handan et al., 2009).

However, there is still very limited knowledge on the manners that soil bulk density levels influence the safflower crop in the Cerrado of Mato Grosso State, particularly in terms of the agronomic features of this cultivar. Therefore, knowledge regarding the adaptation of the safflower genotypes to the Cerrado is crucial. The objective of this study is to assess the influence of soil bulk density levels on the agronomic performance of some important safflower genotypes.

\section{Results and discussion}

\section{Total shoot dry mass}

The total shoot dry mass of the entire was affected by the safflower genotypes and soil bulk density levels in isolation. The genotypes PI 250196, PI 301049, PI 305173, PI 305205 and PI 613366 were found to produce the highest amount of dry mass, when compared statistically with the other genotypes (Fig 1A).

The highest total shoot dry mass may ease the choice of safflower genotypes because this value could result in selecting the plants with the greater yield potential.

This variable was observed to be influenced by the soil bulk density levels, setting the quadratic regression model with the increased production of $104.10 \mathrm{~g} \mathrm{pot}^{-1}$ density $1.10 \mathrm{Mg}$ $\mathrm{m}^{-3}$ (Fig 1B).

A research examining the soil bulk density levels in Oxisol in two wheat cultivars discovered that the highest shoot dry mass production occurred in bulk density of $1.05 \mathrm{Mg} \mathrm{m}^{-3}$ (Bonfim-Silva et al., 2011). Similar values were observed in this study, revealing that even cultures of different botanical families may show a significant drop in the development of the aerial parts of the plants, resulting to increased compression levels in Oxisol. Rosolem et al. (1994) also found that in the absence of inoculation, the increasing soil bulk density of $1.03 ; 1.25 ; 1.48$ and $1.72 \mathrm{Mg} \mathrm{m}^{-3}$ resulted in a remarkable reduction in the total dry weight of the aerial part in soybean.

\section{Root dry mass in 0.0-0.1 m layer}

The root dry mass in the 0.0-0.1 m layer was affected by the safflower genotypes and bulk density in isolation. The PI 250196, PI 305173 and PI 306596 genotypes were found to produce greater dry matter, when compared statistically with the other genotypes. The PI 301049 and PI 613366 genotypes showed no change. The other genotypes PI 237538, PI 248385, PI 305205, PI 306603 and PI 560202 produced lower root dry mass that layer (Fig 2A).

In terms of the bulk density levels, it was adjusted to a quadratic regression model, in which the density of $1.31 \mathrm{Mg}$ $\mathrm{m}^{-3}$ revealed a higher yield, $7.62 \mathrm{~g} \mathrm{pot}^{-1}$ (Fig 2B). Marschner (1986) proposed that with no limitations on water or nutrients, the concentration of the plant roots in the soil layers is greater because their growth is easier as they can grow with minimum absorption of water and nutrients. Similar results were reported by Rosolem et al. (1994), who observed that most of the roots were found concentrated in the 0.0-0.15 $\mathrm{m}$ layer of the pot when the bulk density was $1.72 \mathrm{Mg} \mathrm{m}^{-3}$. Thus, when the roots are developing, physical changes occur in their morphology, with a decrease in growth and increase in diameter (Borges et al., 1988). Hakansson et al. (1998) observed that excessively loose soils show reduced production due to less contact between the soil and root, resulting in the decreased ability of the root system to absorb the essential quantities of water and nutrients.

\section{Root Dry Mass in 0.1-0.2 m layer}

No significant effect was observed among the safflower genotypes for root dry mass in the 0.1-0.2 m layer. Only an isolated effect on bulk density was noted that adjusted the quadratic regression model (Fig $3 \mathrm{~A}$ ). With the rise in bulk density, the root dry mass dropped in the compacted layer to about $31,57,74$ and $84 \%$ in thickness of $1.2,1.4,1.6$ and $1.8 \mathrm{mg} \mathrm{m}^{-3}$, respectively, in the density of $1.0 \mathrm{Mg} \mathrm{m}^{-3}$ (Fig $3 \mathrm{~A})$. This clearly reveals a resistance experienced by the safflower roots in penetrating the compacted soil layer.

All these results concur with those reported by Silva et al. (2012) in which the compacted layer was found to directly influence the quantity of the root dry mass. Bengough and Yong (1993) explored the root development in peas in soil densities of $0.85,1.10,1.3$ to $1.4 \mathrm{Mg} \mathrm{m}^{-3}$ and recorded the observed increase in resistance to the penetration by the roots in the compressed layer.

\section{Root dry mass in 0.2-0.3 m layer}

The root dry mass in the $0.2-0.3 \mathrm{~m}$ layer was affected only by the safflower genotypes and soil bulk density (Fig 3B). The PI 250196 genotype was observed to produce greater amounts of dry mass on average, when statistically compared with the production of the other genotypes at $16 \mathrm{~g} \mathrm{pot}^{-1}$.

For soil bulk density, the root dry mass at 0.2-0.3 m layer conformed to the linear regression model (Fig, 3C). It showed a difference of $85.96 \%$ from the lowest bulk density $\left(1.0 \mathrm{Mg} \mathrm{m}^{-3}\right)$ to the higher bulk density $\left(1.8 \mathrm{Mg} \mathrm{m}^{-3}\right)$ in the experimental interval. Roots were present in this layer, although in some experimental units with soil bulk density of $1.6 \mathrm{Mg} \mathrm{m}^{-3}$ and $1.8 \mathrm{mg} \mathrm{m}^{-3}$ they reached the $0.2-0.3 \mathrm{~m}$ layer of the pot side wall. The quantity of roots produced in the 0.2-0.3 m layer was influenced by soil bulk density, which revealed that the genotype did not break through the compacted layer, i.e. there was a physical barrier which impeded the development of safflower. Beutler and Centurion (2004) studied the effects of soil compaction on root development and reported that the reduced root system in the rings with higher bulk density levels occurs because of the increased resistance to penetration. In the rings with the lower density, greater number of roots was observed. They distributed around the ring, different from the situation in the rings with higher bulk density, in which 

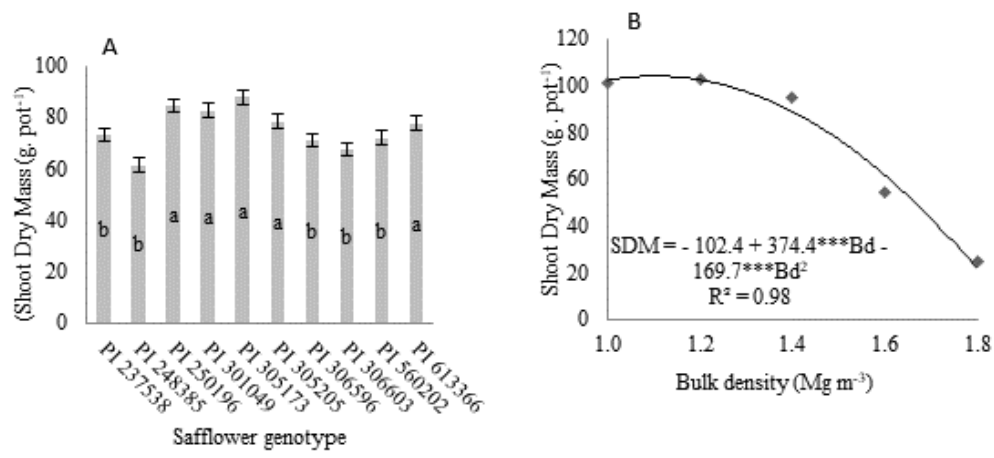

Fig 1. Total shoot dry mass of safflower genotypes. Means followed by the same letter show no difference by the Scott Knott test at $5 \%$ probability (A). Total shoot dry mass of the safflower based on the bulk density levels. Bd - Bulk density. ${ }^{* * *} \mathrm{P}<0.001$, by $\mathrm{F}$ test (B).
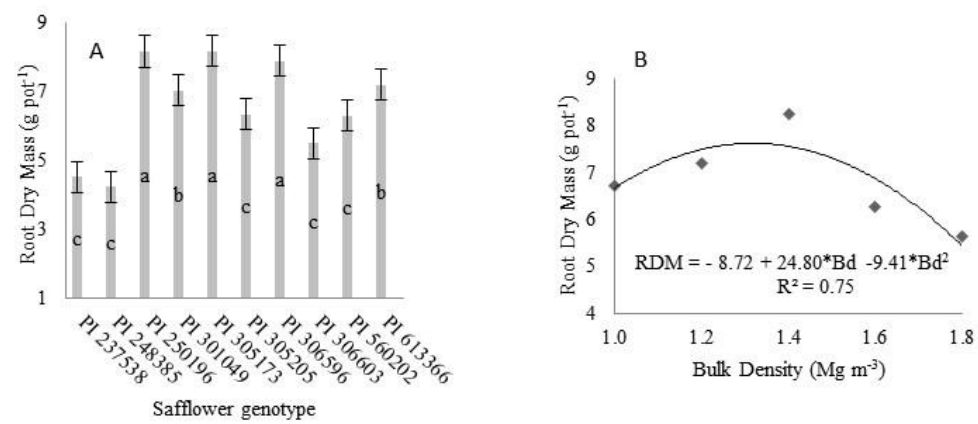

Fig 2. Root dry mass of upper ring of the safflower genotypes. Means followed by the same letter show no difference by the Scott Knott test at $5 \%$ probability $(A)$. Root dry mass of the safflower layer $(0-0.01 \mathrm{~m})$ based on the bulk density levels. RDMU - Root dry mass of upper ring; $\mathrm{Bd}$ - Bulk density. ${ }^{*} \mathrm{P}<0.05$ by $\mathrm{F}$ test $(\mathrm{B})$.
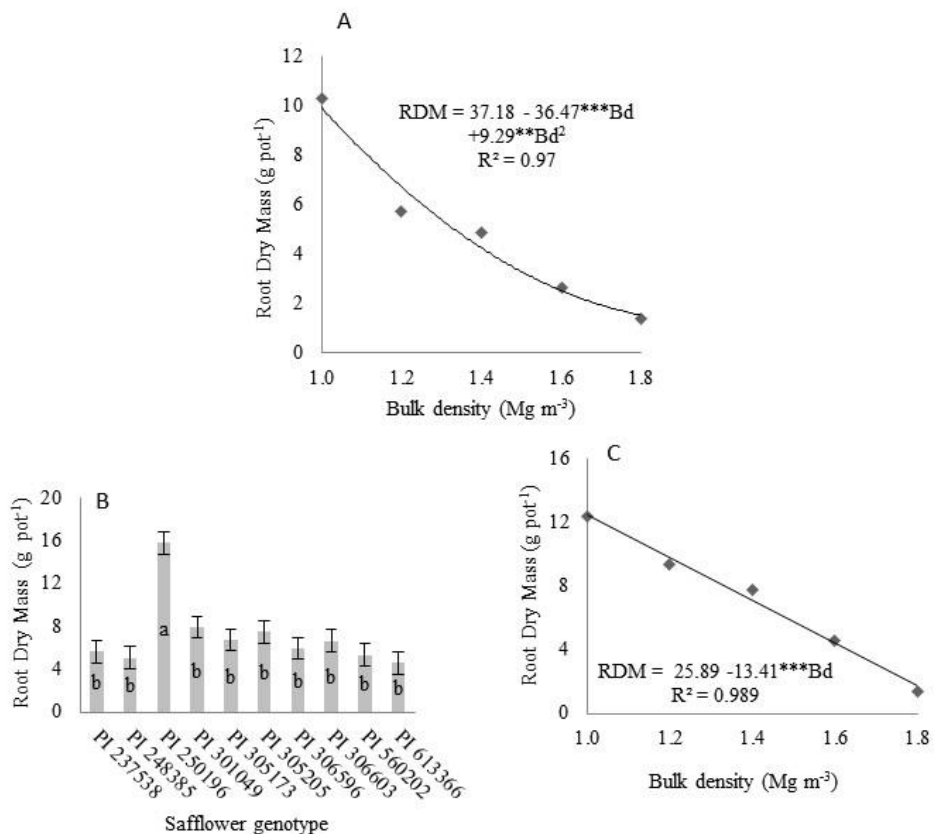

Fig 3. Root dry mass in the lower ring of the safflower genotypes of was dependent on bulk density levels. Bd - Bulk density. ${ }^{* *} \mathrm{P}<$ $0.01 \mathrm{e}^{* * *} \mathrm{P}<0.001$, by $\mathrm{F}$ test $(\mathrm{A})$. Root dry mass in the lower ring of the safflower genotypes in the $0.2-0.3 \mathrm{~m}$ layer. Means followed by the same letter show no difference by the Scott Knott test at $5 \%$ probability (B). Root dry mass in the lower ring of the safflower genotypes in the 0.2-0.3 m layer is dependent on the bulk density levels. Bd - Bulk density. ${ }^{* * *} \mathrm{P}<0.001$, by the $\mathrm{F}$ test (C). 

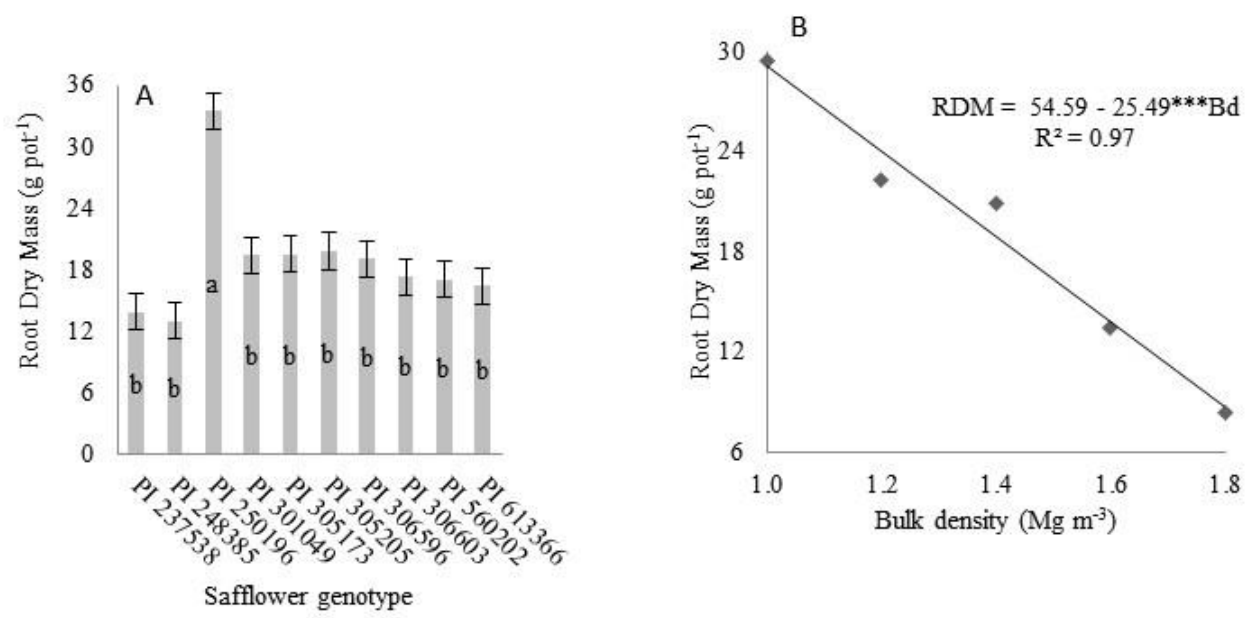

Fig 4. Total root dry mass of the safflower genotypes studied. Means followed by the same letter show no difference using the Scott Knott test at $5 \%$ probability (A). The total root dry mass of the safflower genotypes was found to depend on the bulk density levels. Bd - Bulk density. ${ }^{* * *} \mathrm{P}<0.001$, by the $\mathrm{F}(\mathrm{B})$ test.

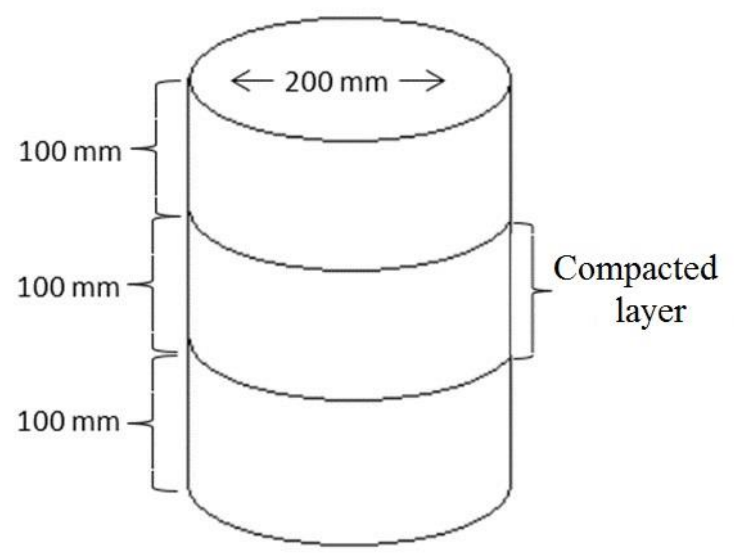

Fig 5. The experimental unit which represents the location of the compacted layer from $0.10 \mathrm{~m}$ to $0.30 \mathrm{~m}$ composition of the experimental units.

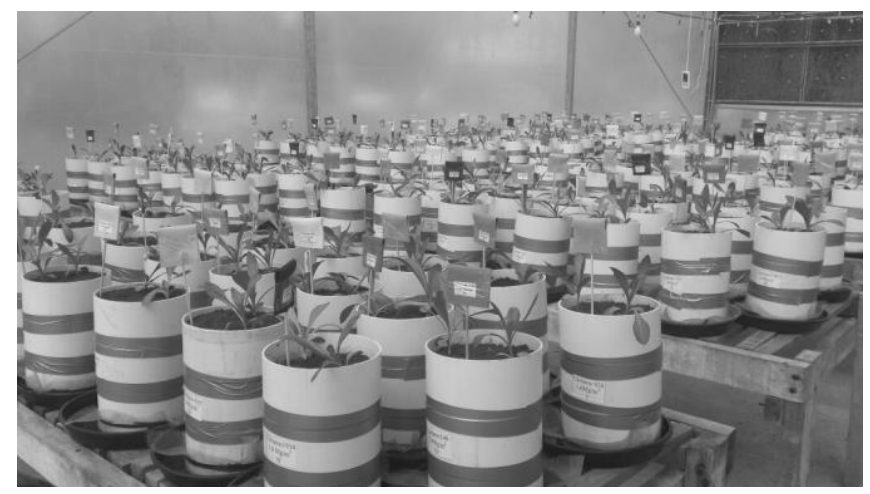

Fig 6. Overview of the experiment performed in the greenhouse on day $15 \mathrm{DAE}$. 
the fine roots were found concentrated in $0.05 \mathrm{~m}$ of the surface layer with only a few thick roots growing deeper.

\section{Total root dry mass in 0.0-0.3 m layer}

The total root dry mass $(0.0-0.3 \mathrm{~m})$ also showed an isolated effect of bulk density on the safflower genotypes. The PI 250196 was seen to show a higher mass yield of $33.49 \mathrm{~g} \mathrm{pot}^{-}$ ${ }^{1}$ when statistically compared with the other genotypes. The production was $40.79 \%$ higher than that of the genotype PI 305205 which produced $19.83 \mathrm{~g} \mathrm{pot}^{-1}$ (Fig 4A).

The total root dry mass of the variable conformed to the linear regression model. Increased bulk density dropped by $71.11 \%$ in the dry mass production of the full root to the point that it raised the bulk density level (Fig 4B).

The results from this study confirm those reported by Rosolem et al. (1994) recorded that soil compaction decreased the root dry mass in soybean.

Hoad et al. (2001) reported that the factors most affecting root growth system of plants like wheat, barley and oats are the resistance to penetration, pore size distribution, and availability of water and nutrient. The shorter and thicker roots offer a reduced area of contact between the soil and root. Therefore, roots have a lower transport resistance compared with the xylem of the fine roots; thus, decreasing the nutrient absorption and consequently hindering plant development.

\section{Materials and methods}

\section{Location of experiment}

The experiment was performed in a greenhouse at the Federal University of Mato Grosso Campus of Rondonópolis, Mato Grosso State, under the Graduate Program in Agricultural Engineering, with the following geographical coordinates, 16028'15" south latitude and 50938'08" west longitude, at $284 \mathrm{~m}$ altitude. The temperature was kept at an average of $28.4^{\circ} \mathrm{C}$ in the greenhouse during the period with a relative humidity of $67.8 \%$.

\section{Soil characterization and fertilization}

The soil was collected in an Oxisol under Cerrado vegetation in the layer of $0-0.20 \mathrm{~m}$ and sieved through a $4 \mathrm{~mm}$ mesh to fill the pots and then passed through a $2 \mathrm{~mm}$ mesh to characterize the chemicals and particle size and $\mathrm{pH}$, respectively $\left(\mathrm{CaCl}_{2}\right)=4.0$; exchangeable $\left.\mathrm{Al}(\mathrm{cmolc} \mathrm{dm})^{-3}\right)=$ 0.8; Ca $\left(\mathrm{cmolc} \mathrm{dm}^{-3}\right)=0.4 ; \mathrm{Mg}\left(\mathrm{cmolc} \mathrm{dm}^{-3}\right)=0.2 ; \mathrm{P}$ (Mehlich) $\left(\mathrm{mg} \mathrm{dm}^{-3}\right)=1.4 ; \mathrm{K}\left(\mathrm{mg} \mathrm{dm}^{-3}\right)=23$; organic matter $\left(\mathrm{g} \mathrm{dm}^{-3}\right)=$ 27.1; $\mathrm{V}(\%)=9.7$; clay $\left(\mathrm{g} \mathrm{kg}^{-1}\right)=444$; sand $\left(\mathrm{g} \mathrm{kg}^{-1}\right)=423$; silt $(\mathrm{g}$ $\left.\mathrm{kg}^{-1}\right)=133$.

Once the soil was collected and sifted it was packaged in $14 \mathrm{dm}^{3}$ plastic bags. Liming was then done to correct its acidity, which was calculated using the base saturation method (Raij, 1991). Dolomite lime (80.3\%, Relative Power of Total Neutralization - RPTN) was done to raise the base saturation of $60 \%$ (Anicésio et al., 2015).

Fertilizer was applied using 200, 150, $200 \mathrm{mg} \mathrm{dm}^{-3}$ of nitrogen, phosphorus $\left(\mathrm{P}_{2} \mathrm{O}_{5}\right)$ and potassium $\left(\mathrm{K}_{2} \mathrm{O}\right)$, as urea, potassium chloride and superphosphate, respectively (Bonfim-Silva et al., 2015). Micronutrients were added as
Fritted Trace Elements - FTE BR 12 ( $9 \% \mathrm{Zn}, 1.8 \%$ B, 0.8\% Cu, $2 \% \mathrm{Mn}, 3.5 \% \mathrm{Fe}, 0.1 \% \mathrm{Mo}$ ) by applying $15 \mathrm{mg} \mathrm{dm}^{-3}$. The soil was enriched with phosphorus fertilizer, potassium and nitrogen prior to the compaction treatment and installation of the experiment.

\section{Experimental unit and soil compaction}

Each experimental unit involved a pot of 9,423 $\mathrm{dm}^{-3}$ volume, made up of hard PVC pipe (Polyvinyl chloride) with $200 \mathrm{~mm}$ internal diameter, $300 \mathrm{~mm}$ height, with three overlapping rings $100 \mathrm{~mm}$ (Fig 5) held together with duct tape.

A 1-mm polyethylene mesh screen was placed at the base of the experimental unit to hold it to the ground. Next, plastic dishes with $300 \mathrm{~mm}$ diameter were placed beneath each experimental unit to serve as the container base.

Soil compaction was accomplished using a Bovenau hydraulic press, model P15ST. The intermediate ring had compression levels that varied with the treatments (bulk densities of $1.0,1.2,1.4,1.6$ and $1.8 \mathrm{Mg} \mathrm{m}^{-3}$ ), whereas the upper and lower rings contained soil masses equivalent to maintain the bulk density at $1.0 \mathrm{Mg} \mathrm{m}^{-3}$ corresponding to $3.140 \mathrm{dm}^{3}$ of soil.

The density to achieve solo compression occured under a given compaction energy based on the soil moisture at the time of compression (Caputo and Caputo, 2015). Compression laboratory tests (normal Proctor test) were performed prior to establish the ideal moisture compression by $16 \%$ of the mass base.

To achieve the required compression levels, specific amounts of soil were added to the intermediate ring which was filled with different bulk density levels $(1.0,1.2,1.4,1.6$ and $1.8 \mathrm{Mg} \mathrm{m}^{-3}$ ).

\section{Genotypes of safflower}

For this study, we selected ten safflower genotypes from the genetic material of the BAG (Bank Active Germplasm) from Mato Grosso Institute Cotton - IMA. The seeds selected were produced in the experimental field in the municipality of Primavera do Leste - MT. The PI 237538, PI 248385, PI 250196, PI 301049, PI 305173, PI 305205, PI 306596, PI 306603, PI 560202 and PI 613366 were the genotypes used. In each pot, twenty seeds were planted in $0.02 \mathrm{~m}$ depth. Two days post sowing seedlings emerged. At days five, seven and fifteen DAE thinning was done, until ten, six and two plants per pot remained, respectively (Fig 6).

\section{Irrigation management}

Using surface irrigation on the pot surface, the soil moisture was maintained to establish the plants. After 15 DAE moisture was maintained by capillary action by adding water to the dishes placed under the pots, encouraging the plants to overcome the compacted subsurface layer that acts as a barrier for absorption of water and nutrients (Silva et al., 2006).

\section{Experimental design}

A completely randomized design was chosen for the experiment in factorial scheme. Ten safflower genotypes 
and five soil bulk density levels (1.0, 1.2, 1.4, 1.6 and $1.8 \mathrm{Mg}$ $\mathrm{m}^{-3}$ ) were used in four repetitions, totaling to 200 experimental plots (Fig 6).

\section{Evaluation of variables}

Assessments were done at $90 \mathrm{DAE}$. The data on the total shoot dry mass (TSDM), root dry mass of upper ring (RDMU), root dry mass in the compacted ring/intermediate (RDMC) and root dry mass in the lower ring (RDML) and total root dry mass (TRDM) were collected.

All the material collected was packed in paper bags and dried in a forced-air oven at $65^{\circ} \mathrm{C}$ for 72 hours, and then weighed on a precision scale.

\section{Statistical analysis}

The results were subjected to statistical analysis using the Sisvar program (Ferreira, 2011). The data were submitted to variance analysis. When the significant qualitative variables (genotypes) were submitted to Scott-Knott grouping test (Scott and Knott, 1974) and the quantitative variables (bulk density levels) were subjected to regression analysis. The significance level of up to $5 \%$ probability of error was used for all the statistical analyses.

\section{Conclusion}

The genotypes and soil density influenced the components evaluated in isolation way. The shoot dry mass production was impaired from the bulk density of $1.10 \mathrm{Mg} \mathrm{m}^{-3}$. For the root dry mass, the limit is $1.04 \mathrm{Mg} \mathrm{m}^{-3}$. In general, from the soil density of $1.20 \mathrm{Mg} \mathrm{m}^{-3}$ the growth and development of safflower genotypes were influenced negatively. The increase in soil density reduced the total root dry mass up to $71.11 \%$.

\section{Acknowledgments}

The authors extend their gratitude to IMA (Mato Grosso Cotton Institute) for supplying the seeds of the safflower genotypes, and UNESP (Universidade Estadual Paulista Julio de Mesquita Filho), for their support in running this experiment. The authors express gratitude to CAPES and the CNPq for funding this project.

\section{References}

Anicésio ECA, Bonfim-Silva EM, Silva TJA, Koetz M (2015) Dry mass, nutrient concentration and accumulation in safflower (Carthamus tinctorius L.) influenced by nitrogen and potassium fertilizations. Aust J Crop Sci. 6: 2136-2143.

Bengough AG, Young IM (1993) Root elongation of seedling peas through layered soil of different penetration resistances. Plant Soil. 149: 129-139.

Beutler AN, Centurion JF (2004) Compactação do solo no desenvolvimento radicular e na produtividade da soja. Pesq Agropec Bras. 39: 581-588.

Bonfim-Silva EM, Anicésio ECA, Silva FCM, Dourado LGA, Aguero NF (2011) Compactação do solo na cultura do trigo em Latossolo do Cerrado. Encicl Biosf. 7: 1-8.
Bonfim-Silva EM, Paludo JTS, Sousa JVR, Sousa HHF, Silva TJA (2015) Development of Safflower Subjected to Nitrogen Rates in Cerrado Soil. Am J Plant Sci. 6: 2136-2143.

Borges EN, Novais RF, Regazzi AJ (1988) Resposta de variedades de soja à compactação de camadas do solo. $R$ Ceres. 35: 553-568.

Caputo HP, Caputo AN (2015) Mecânica dos solos e suas aplicações. $7^{\text {th }}$ Edition. LTC.

Coronado LM (2010) El cultivo del cártamo (Carthamus tinctorius L.) en México. Instituto nacional de investigacion esforestales, agrícolas y pecuárias. México. 98 pp.

Ferreira DF (2011) Sisvar: a computer statistical analysis system. Ciênc Agrotec. 35: 1039-1042.

Hakansson I, Stenberg M, Rydberg T (1998) Long term experiments with different depths of mould board plough in Sweden. Soil Till Res. 46: 209-223.

Handan Y, Pérez-Vich B, Velasco L, Fernández-Martínez JM (2009) Inheritance of high oleic acid content in safflower. Euphytica. 68: 1-69.

Hoad SP, Russel G, Lucas ME, Bingham IJ (2001) The management of wheat, barley, and oat root systems. Adv Agron. 74: 195-254.

Leite LFC, Arruda FP, Costa CN, Ferreira JS, Holanda Neto MR (2013) Qualidade química do solo e dinâmica de carbono sob monocultivo e consórcio de macaúba e pastagem. R Bras Eng Agrc Amb. 17: 1257-1263.

Marasca I, Oliveira CAA, Guimarães EC, Cunha JPAR, Assis RL, Perin A, Menezes LAS (2011) Variabilidade espacial da resistência do solo à penetração e teor de água em sistema de plantio direto, na cultura da soja. Bioscience J. 27: 239-246.

Marschner H (1986) Mineral nutrition of higher plants. Academic Press.

Paludo JTS, Bonfim-Silva EM, Silva TJA, Zanotto MD, Fenner W, Koetz M (2017) Reproductive components of safflower genotypes submitted of bulk density levels in the Brazilian Cerrado. Am J Plant Sci. 8: 2069-2082.

Raij BV (1991) Fertilidade do solo e adubação. Potafós.

Rosolem CA, Almeida ACS, Sacramento LVS (1994) Sistema radicular e nutrição da soja em função da compactação do solo. Bragantia, 53: 259-266.

Scott AJ, Knott M (1974) A cluster analysis method for grouping means in the analysis of variance. Biometrics. 30 : 507-512.

Silva GJ, Maia JCS, Bianchini A (2006) Crescimento da parte aérea de plantas cultivadas em vaso, submetidas à irrigação subsuperficial e a diferentes graus de compactação de um Latossolo Vermelho-Escuro distrófico. R Bras Ciênc Solo, 30: 31-40.

Silva SD, Alves JM, Mesquita GM, Leandro WM (2012) Efeito da compactação do solo no desenvolvimento aéreo e radicular do pinhão manso (Jatropha curcas L.) e crambe (Crambe abyssinica Hochst). Global Sci Tech. 5: 87-97.

Valicheski RR, Grossklaus F, Sturmer SLK, Tramontin AL, Baade ESAS (2012) Desenvolvimento de plantas de cobertura e produtividade da soja conforme atributos físicos em solo compactado. R Bras Eng Agríc Amb. 16: 969-977. 